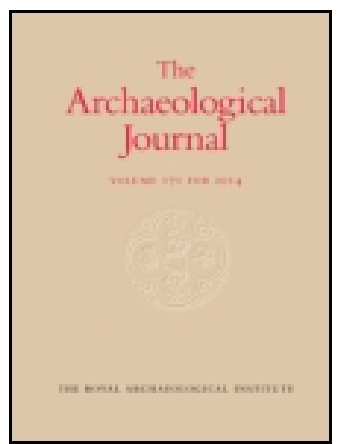

Archaeological Journal

\title{
Pre-Norman Churches and Sepulchral Monuments of Nottinghamshire
}

\author{
the Rev. A. du Boulay Hill M.A.
}

To cite this article: the Rev. A. du Boulay Hill M.A. (1916) Pre-Norman Churches and Sepulchral Monuments of Nottinghamshire, Archaeological Journal, 73:1, 195-206, DOI: 10.1080/00665983.1916.10853301

To link to this article: http://dx.doi.org/10.1080/00665983.1916.10853301

曲 Published online: 17 Jul 2014.

Submit your article to this journal $₫$

Џll Article views: 2

Q View related articles $\square$

Citing articles: 1 View citing articles 5 


\title{
PRE-NORMAN CHURCHES AND SEPULCHRAL MONUMENTS OF NOTTINGHAMSHIRE. ${ }^{1}$
}

\author{
By the Rev. A. DU BoUlay HILl, M.A.
}

Nottinghamshire is by no means rich in Anglo-Saxon remains, but the discovery of a fairly complete plan of a Saxon church may well give occasion for bringing together the evidences that have been found within the county, as a contribution to the history of art and buildings of that period.

In the course of the work of restoration of East Bridgford church, which was carried out in 1902 and r9r4, the foundations of a Saxon church were revealed, occupying the same site, and hidden beneath successive rebuildings of the church at the end of the twelfth and the middle of the fourteenth centuries (fig. I).

On the north side of the chancel, about 12 feet of walling was found beneath the floor, the present north wall being built outside it with a space of 6 ins. between the two walls. It is I ft. Io ins. thick and consists chiefly of large stones, the internal plaster adhering to it and showing the floor-level. The responds of a chancel arch 8 feet wide were in situ, consisting of single blocks, each having a rebate cut on the western angle as if for a wooden screen.

The south wall of the chancel is built upon earlier foundations for 28 feet of its length. About ro feet of the old walling still remains at its western end, pierced by a twelfth-century priest's door and a fifteenth-century low-side-window. Eastward of this the character of the foundations of flat stones set on edge indicate an early Norman chancel wider and longer than the Saxon chancel. Traces of its east wall were found about ro feet from the east end of the present thirteenth-century chancel.

While the pillars of the nave were being underpinned it was possible to trace out the continuation westward

\footnotetext{
I Read before the Institute, Ist March, I916.
} 


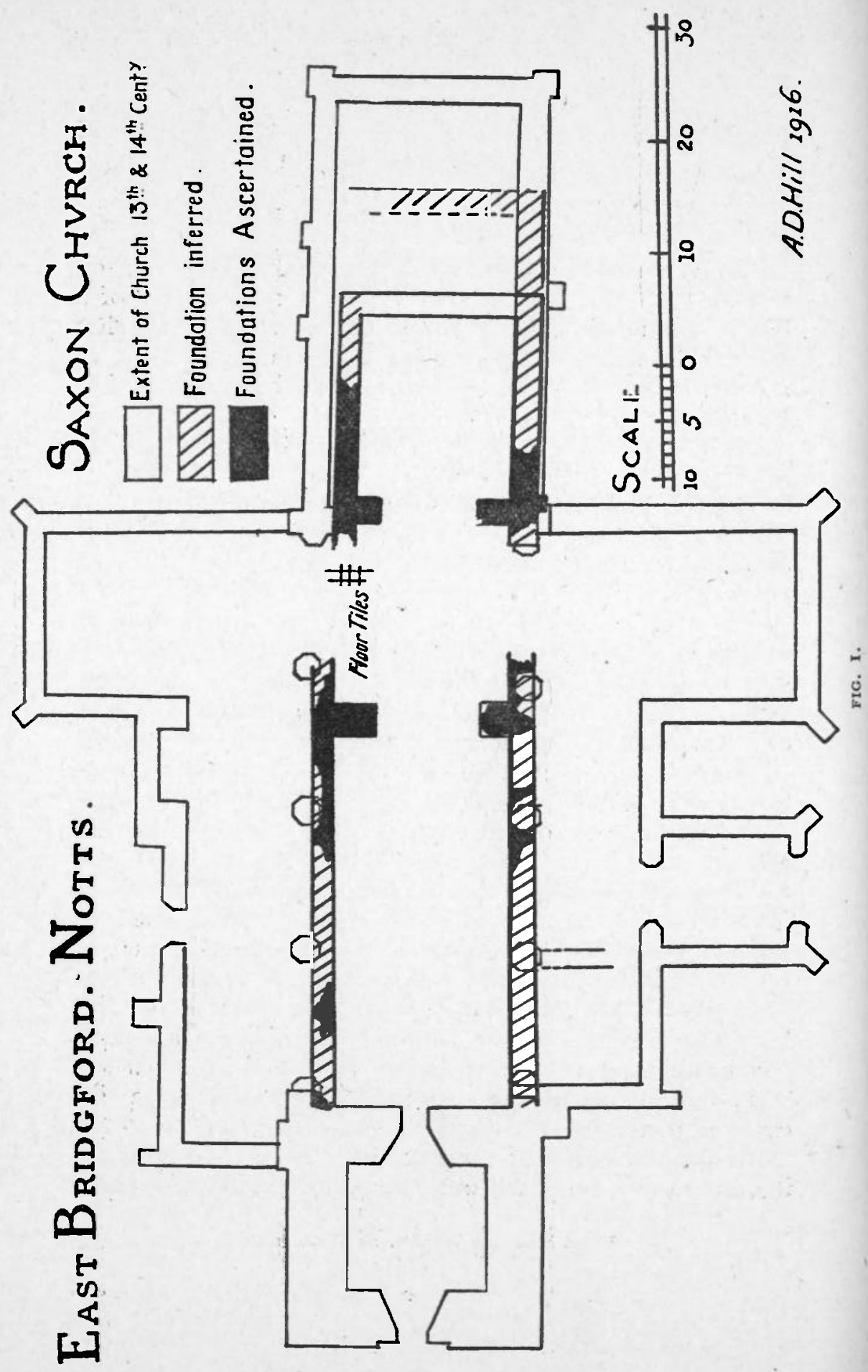


of these foundations. On the south side the arcade is built upon the line of wall, but the north arcade stands from one foot to 18 inches outside the line, which will be seen on the plan with a more marked southward inclination with the axis of the chancel than at present. A thickening of the wall at the western respond indicates the existence of a part of the Saxon work above ground at this point.

A projecting block $4 \mathrm{ft}$. by $3 \mathrm{ft}$. thick, and the remains of a corresponding block on the south side, mark off a nave 32 feet in length from a middle tower or crossingspace $\mathrm{I} 6 \mathrm{ft}$. 6 ins. square.

It will be noticed that the north wall of the nave is not in alignment with the north wall of the chancel, though the responds of the east and west tower arches seem to correspond. This discrepancy may point to a later rebuilding of the north wall of the nave. No actual evidence of transepts was found, except the absence of foundations on the north and south sides of the crossingspace. The work done in the chancel was carried out twelve years before I could examine the nave remains, so it has not been possible to clear up satisfactorily the problem of the junction of nave and chancel. Intramural interments have destroyed the evidences of the east wall of the chancel and the transepts, and I could not venture too near the shaky foundations of the piers. The large stones used in the chancel walls lead one to conclude that this part belongs to an earlier structure than the nave.

Near the entrance to the north transept a few red floor-tiles one foot square were found in situ, I ft. 4 ins. below the present nave floor, indicating that the floor of the nave was about the same level as that of the chancel. Several fragments of round shafts have been turned up, the square base of a small engaged shaft, and a small piece which looks like the bulged centre of a vertically fluted baluster. It is noticeable that the outer surface of all these fragments, which are of yellow Mansfield sandstone, is reddened as though by the action of fire.

Two fragments of a cross-shaft ornamented with interlaced patterns have been found and will be described later. 
Other remains of Saxon churches in Nottinghamshire as known up to the present time are as follows :--

Carlton-In-Lindrick. Here there is a. western tower with mid-wall shafts of the late Lincolnshire type, and the only one in the county.

The belfry stage and the big angle-buttresses were added to it in the fifteenth century, and the old belfry windows were blocked up. The. Saxon tower thus forms, so to speak, the kernel of what at first sight is a handsome fifteenth-century tower in which older work appears to be incorporated.

Plumtree. An early Norman tower here has been built up against the west wall of an earlier church. This wall had a remarkable horizontal chase across it, now hidden by the rebuilt tower, for the reception of a timber pent-house porch at the west end of the church. Herringbone courses below the chase throw some doubt upon its Saxon character, but the wall is certainly much older than the tower. ${ }^{1}$

Southwell. A banded baluster-shaft, found in the quire-foundations, is preserved within the Minster, the sole visible evidence of the church of St. Eadburg.

Warsop. The western part of this greatly rebuilt tower is probably Saxon. There is a horizontal course on its west face of triangular stones fitted together in mosaic manner. ${ }^{2}$

Early foundations or walling, called Saxon, but mostly of herring-bone work and therefore probably Norman, have been found in several churches along the banks of the Trent, Farndon, Averham, Rolleston, S. Muskham, Cromwell, Sutton-on-Trent, Laneham and Littleborough ; also at Oxton, Linby, East and West Leake.

CROSSES AND GRAVE-COVERS.

Of another class of pre-Norman remains, characterised by interlaced ornament, there are in Nottinghamshire

1 Tboroton Soc. Trans. Ig05.

2 ibid. I9I4. 
twelve examples, namely nine cross-shafts and three grave-covers.

\section{Crosses.}

I. Bilsthorpe.

2. Coates, North Leverton.

3. East Bridgford.*

4. Hawksworth.*

5. Kneesall.

6. Rolleston.

7. Screveton.*

8. Shelford.*

9. Stapleford.
Grave-covers. Io. Hickling. ${ }^{*}$

II. Shelton, A.*

I2. Shelton, $\mathrm{B}$ * $^{*}$

Those marked * are in the part of the county south of the Trent, and, with the exception of the grave-cover at Hickling, in a row of five adjoining parishes.

The first seven examples, three in adjoining parishes south of the Trent, and four on the north of the Trent, are very similar in character and ornament. All have strap work of three and four plaits, enclosed in cable borders sometimes very roughly indicated. The straps have a central line marked on them and are in loose plaits. The pattern is occasionally varied by the introduction of circles interlaced by the straps. All the stones have been re-used, probably by the Norman builders who cut up the crosses into blocks and dressed off the ornament for the face they required, thus showing their contempt for the art and religious symbols of their Saxon predecessors.

Bilsthorpe. To the north of the Trent a fragment of a cross-shaft is to be seen at Bilsthorpe, forming the base of a Norman tub-font. The pattern here shows the use of circles among the interlacements.

Contes. There is an example of strap ornament, found at Coates near Littleborough, now in the possession of W. H. Mason, Esq. of Retford. It consists of two fragments of a slab $5 \frac{1}{2}$ ins. thick with cable border and loose carrick-bend interlacements, divided by unusual spindle-shaped rods. It may have been a grave-cover, but $\mathrm{Mr}$. W. Stevenson suggests that it is a laminated split along the line of bedding from a larger block of a cross-shaft. 1 
EAsT BRIDgFord. The cross shaft was a block of Lincolnshire limestone about 7 feet high, the two remaining fragments of which have been used for the arch of a small round-headed window splayed on both sides and rebated for a shutter, about 16 ins. in the opening (fig. 2).

Haw Ksworth. The fine shaft here is $5 \mathrm{ft}$. 9 . ins. high

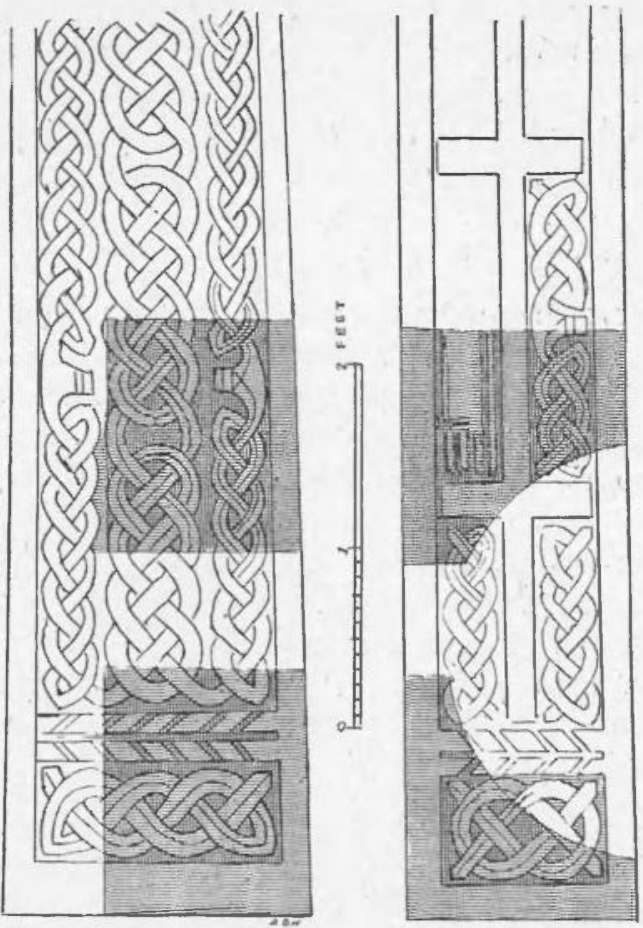

FIG. 2. CROSS-SHAFT, EAST BRIDGFORD $\left(\frac{1}{16}\right)$.

The shaded portions represent the existing remains.

and tapers slightly. It retains its ornament on two sides, the other two having been re-faced. The design is similar to that at East Bridgford, but here the scrolls flow from the ends of the double cross which is on the broad face (fig. 3).

A chamfer $3 \mathrm{ft} .6$ ins. in length has been taken off the edge adjacent to the ornamented sides, and a rebate of 
SEPULCHRAL MONUMENTS OF NOTTINGHAMSHIRE. 2OI

the same length has been worked on the opposite angle of the shaft, indicating that the stone was used by the Normans as the lintel of a doorway to support a remark-

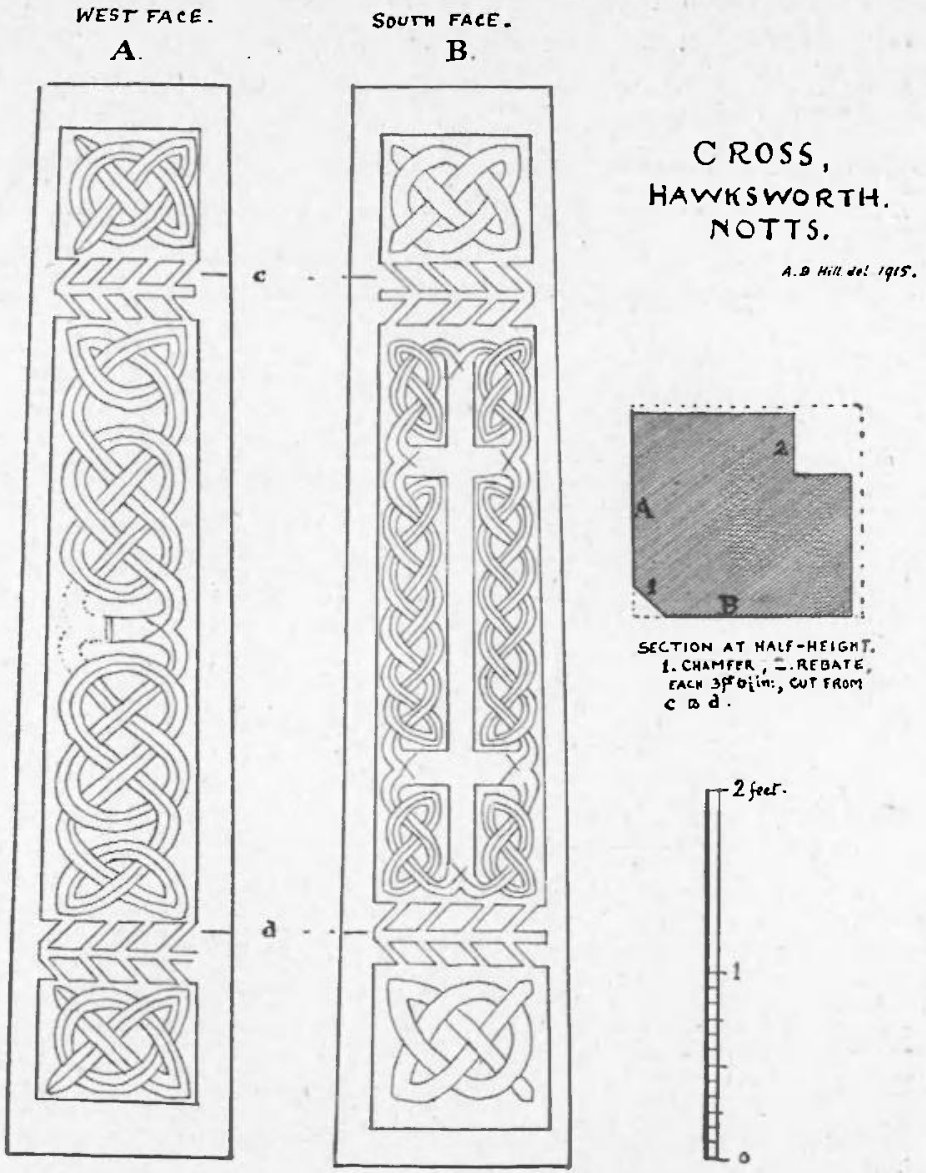

FIG. 3. CROSS-SHAFT, HAWKSWORTH $\left(\frac{1}{16}\right)$.

able tympanum with $l_{a}$ dedicatory inscription of the twelfth century, described in Mr. Keyser's Norman Tympana. This is now built into the south tower-wall, and the cross-shaft has recently been placed for better protection within the church. 
Kneesall, north of the Trent, and near to Bilsthorpe, possesses the fragment of a cross-shaft with a pattern showing the use of circles among the interlacements.

Rolleston, by the left bank of the Trent, has three blocks cut from the shaft of a cross with two sides squared off, which have been used as a door-jamb. The design resembles that of the Hawksworth shaft (plate I).

Fixed in the wall of this church is a small stone of two panels with similar cabled border, though not belonging to the same cross. In the upper panel there

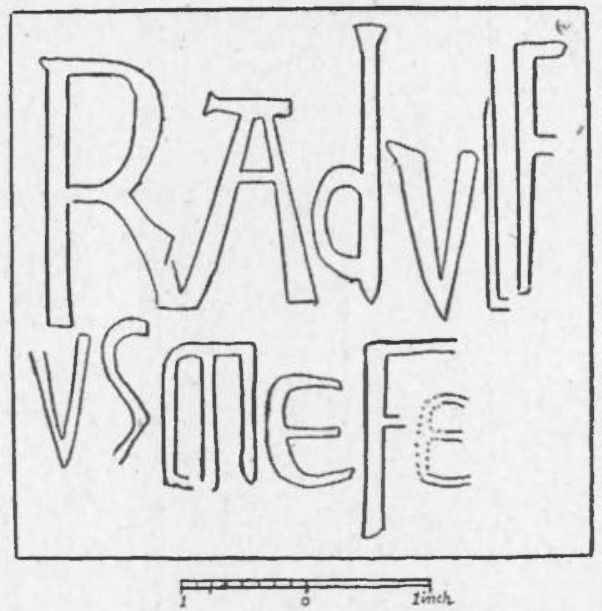

FIG. 4. ROLLESTON CHURCH, NOTTS.

is a bird and a stag in combat, and in the lower panel an inscription: RADULFUS ME FE[CIT] (fig. 4.) Radulfus has a Norman sound, but the name was not unknown among Saxons. The conjecture may be permitted that we have here the name of the humble artist who, carrying on the traditions of the monumental sculptors of over three centuries, supplied all the surviving examples of sepulchral cross-shafts of this type in Nottinghamshire, to six churches within a radius of seven or eight miles from Rolleston.

Screveton. A fragment at this place has a pattern similar to that at East Bridgford remaining on one face. 


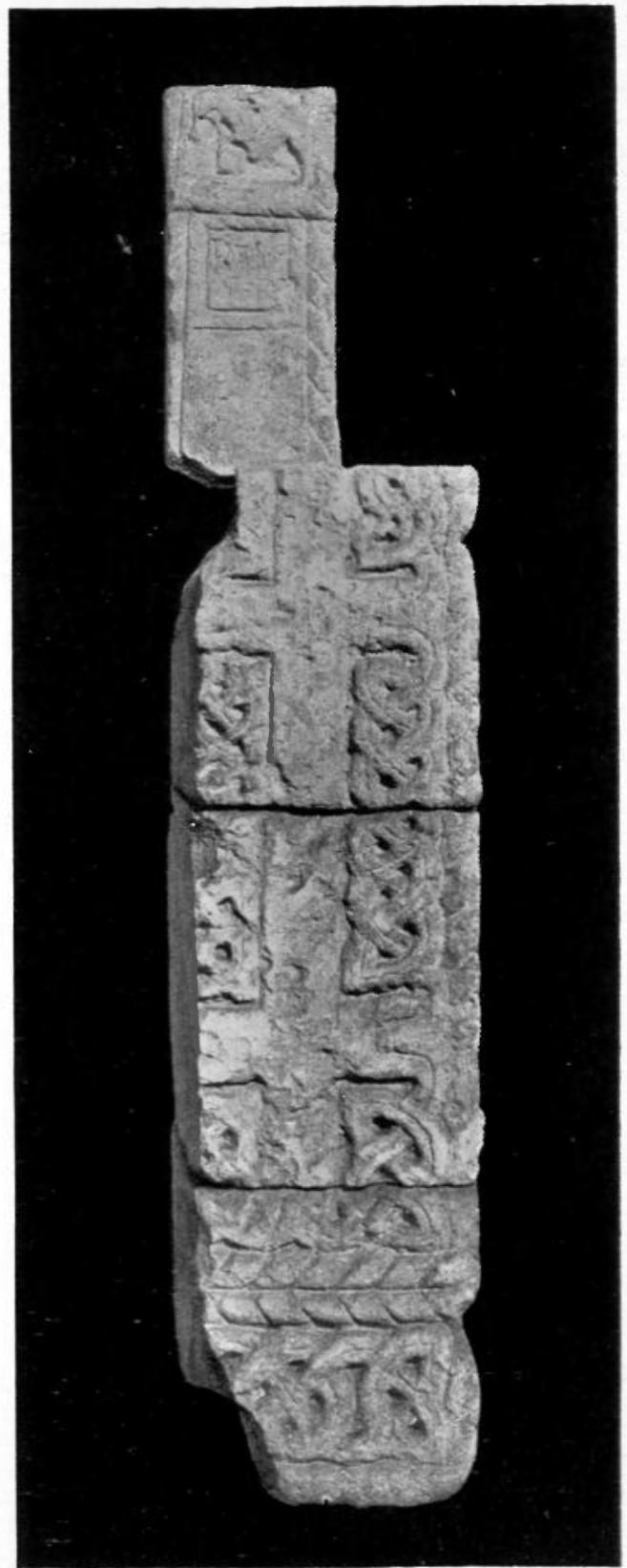

[A. F. Loughton, phot.

CROSS̄-SHAFT AND INSCRIBED STONE, ROLLESTON, NOTTS. 

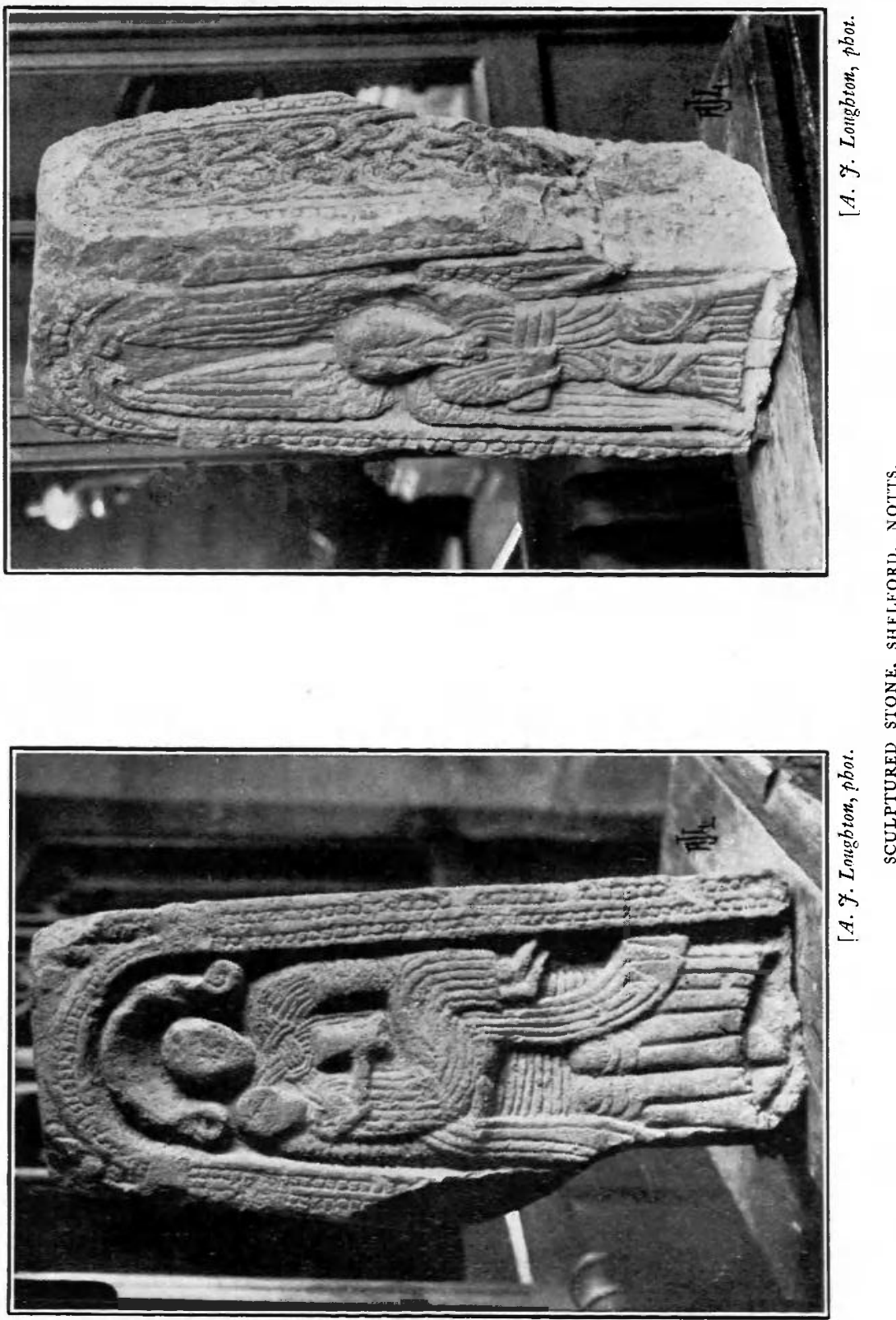
SHELFORD. This is a stone preserved in the church, $2 \mathrm{ft}$. ro ins. high, of a white magnesian limestone. It is the upper part of a shaft of rectangular section having two broad faces with figures carved upon them: (I) a seated figure of the Virgin, with the holy Child holding what looks like a chalice in his right hand. The drapery folds are indicated by close flutings, and the Virgin wears a long scarf, crossed and passing through a large annular brooch. Her semicircular nimbus has scrolled ends (plate II, A, B). (2) A bearded seraph with four wings, a book or roll in his right hand, and the left up-raised. The points of the beard and tips of the upper wings are scrolled. A bar projecting obliquely across his left lower wing may be the tail of some beast beneath his feet which has been lost (plate II, B).

These figures are under round canopies springing from capitals on shafts with beaded ornament which is also continued round the arch. An outer beaded line forms a rectangular border to the whole. On the narrow side a similar canopied panel is filled with closely interlaced strap-work plaits having a central line on them; the interlacements are irregular and imperfectly worked out. The pattern on the fourth side has been cut away, but traces of a spiral ornament can still be discerned.

The beaded border and scrolled tips to wings and beard may be evidence of Scandinavian influence.

Stapleford (plate iII). This is the only example in the county of the earlier type of Anglian monuments. It is a shaft of millstone grit ten feet in height, and is really square in section with rounded angles, which makes it appear cylindrical except at the top which has four faces. On one face alone a figure is to be seen, which Bishop G. F. Browne ${ }^{1}$ considers the emblem of St. Luke, an ox with horns. On the other faces there is interlaced work. Below are two broad bands of ornament, partly foliaged scrollwork, and partly strap-work closely interlaced with marvellous intricacy. This fine monument, erected perhaps in the eighth century, stands close to a tributary of the Trent, which forms the south-western border of the 
county. It may have had a civil as well as an ecclesiastical significance, marking the limit of the Northumbrian influence which had extended into the Mercian kingdom.

\section{GRAVE-COVERS.}

Hicking. A remarkably perfect and unique gravecover was dug up in the churchyard early in the last century and is now fixed upright against the east wall of the south aisle of the church (fig. 5). The slab is about 5 ins. thick at the edges, rising to one foot at the slightly coped ridge. Bishop G. F. Browne, who kindly allows me to copy the drawing made for his Disney lectures, has thus described it :

The bar which forms the ridge piece, and the stem of the very pretty cross, passes out of the snout of a bear at each end. The bear clutches the stone with his forepaws. This is a Scandinavian survival, from the practice of casting a bearskin over the body of a warrior. It is a feature of the Anglo-Saxon 'hog-back' stones of which there are many in Yorkshire. This is at least a very unusual application of it to a flat grave-stone.

The upper surface of the stone is irregularly panelled and covered with a variety of lacertine scrolls and knotwork. The sides have a two-cord design, of knots on one side, and on the other interlaced with circles. The dots which occur in rows or filling up spaces are a Scandinavian feature. The work is of the Jellinge type and may therefore be assigned to the last half of the tenth century.

Shelton. In this church are two massive blocks, each of them being the foot half of a grave-cover, ornamented on the top and sides.

(Plate Iv, A). The earliest cover has a straight-sided keel forming the ridge-piece and running into the roundtopped raised foot-end. The flat surfaces on either side of the ridge, the rounded end and the sides are covered with closely interlaced three-plait and four-plait strap ornament.

(Plate Iv, B). The second grave-cover is hog-backed and coped. The ridge is a double cable which separates along the edges of the hipped foot enclosing a triquetral 


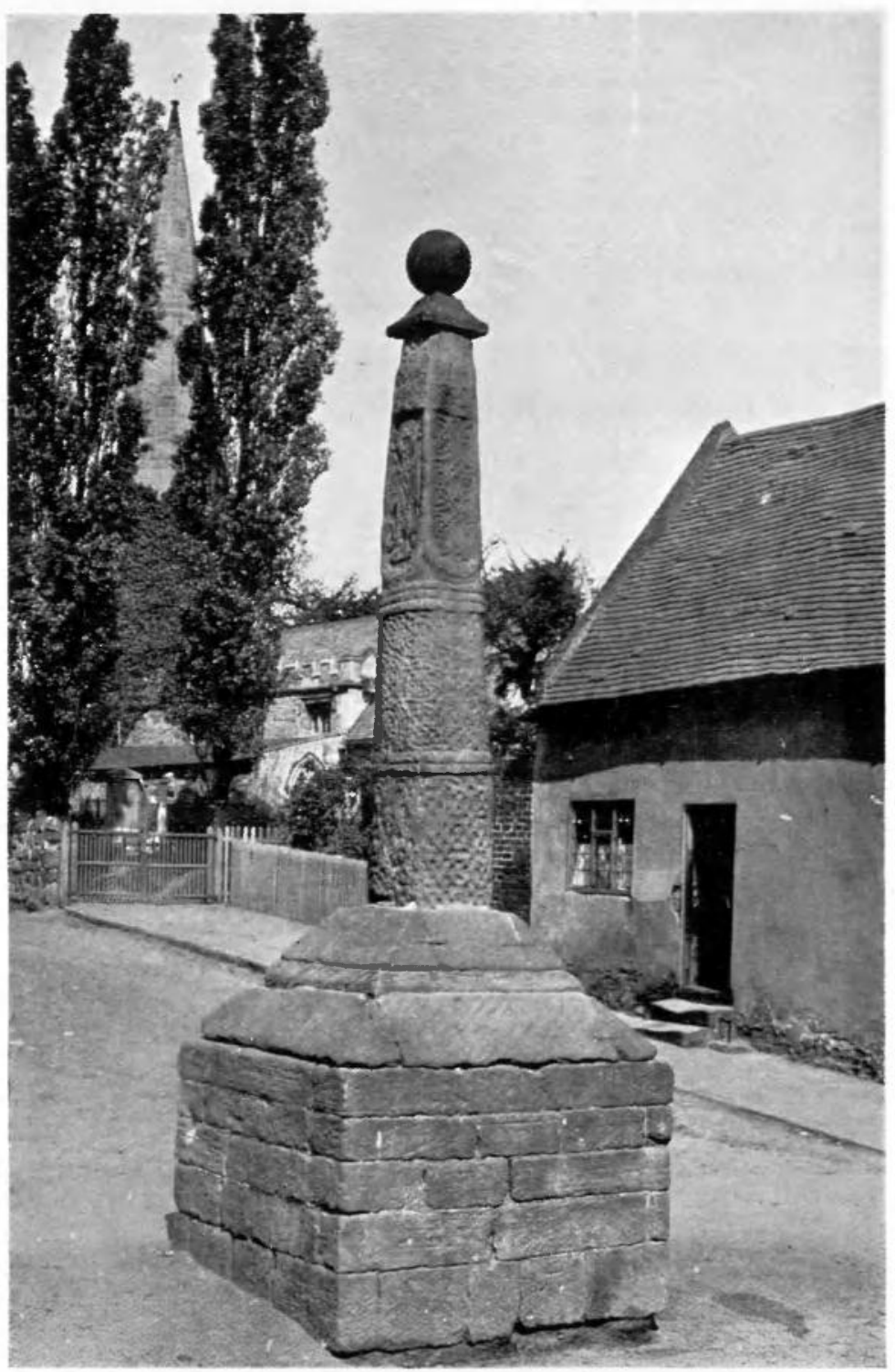

STAPLEFORD CROSS, NOTTS. 

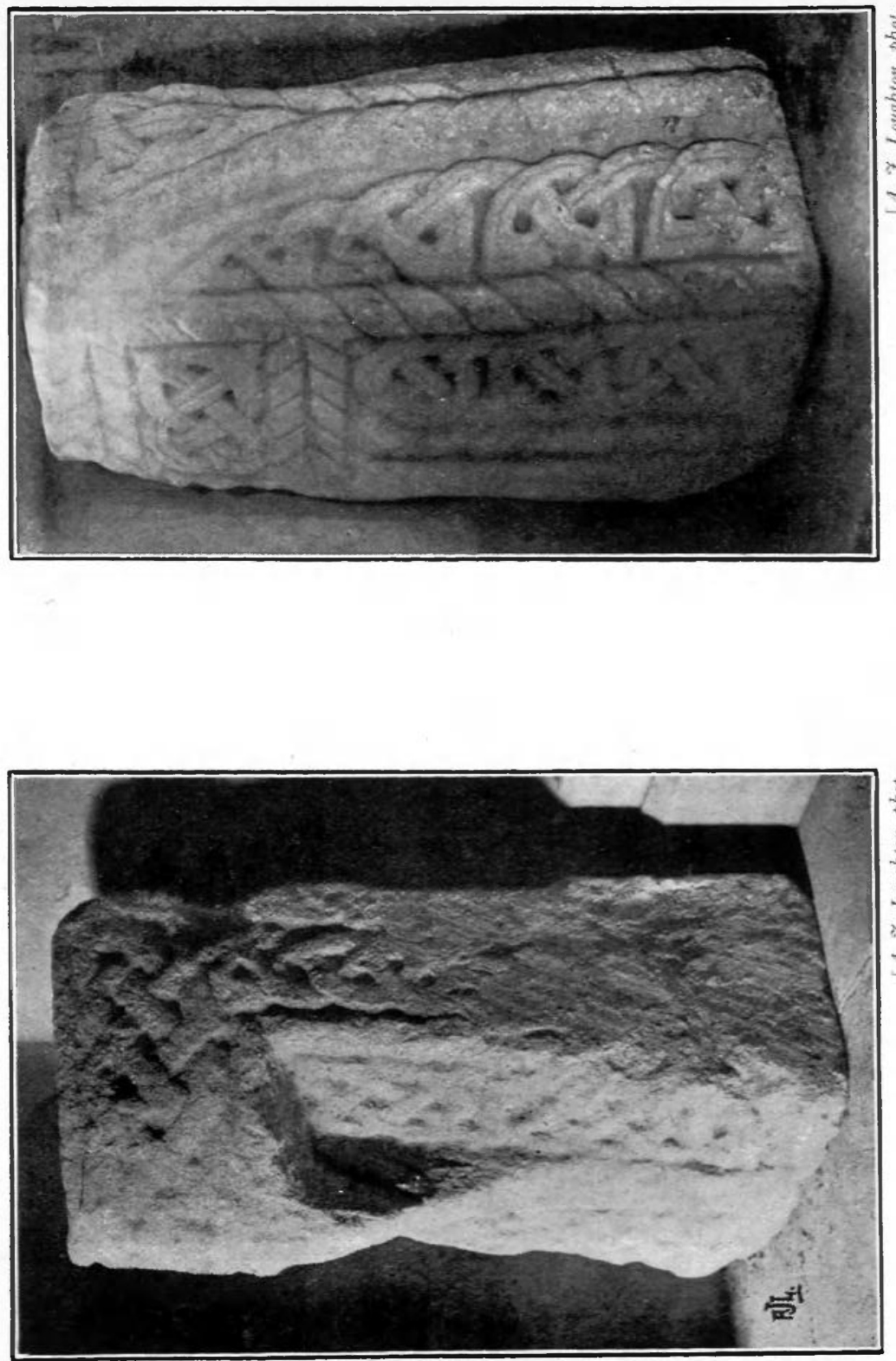

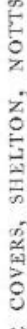


SEPULCHRAL MONUMENTS OF NOTTINGHAMSHIRE. 205

knot. The sloped surfaces of the coping are ornamented with a loosely-knotted single strap, and the sides are divided into panels by cabled borders with circles and interlace-
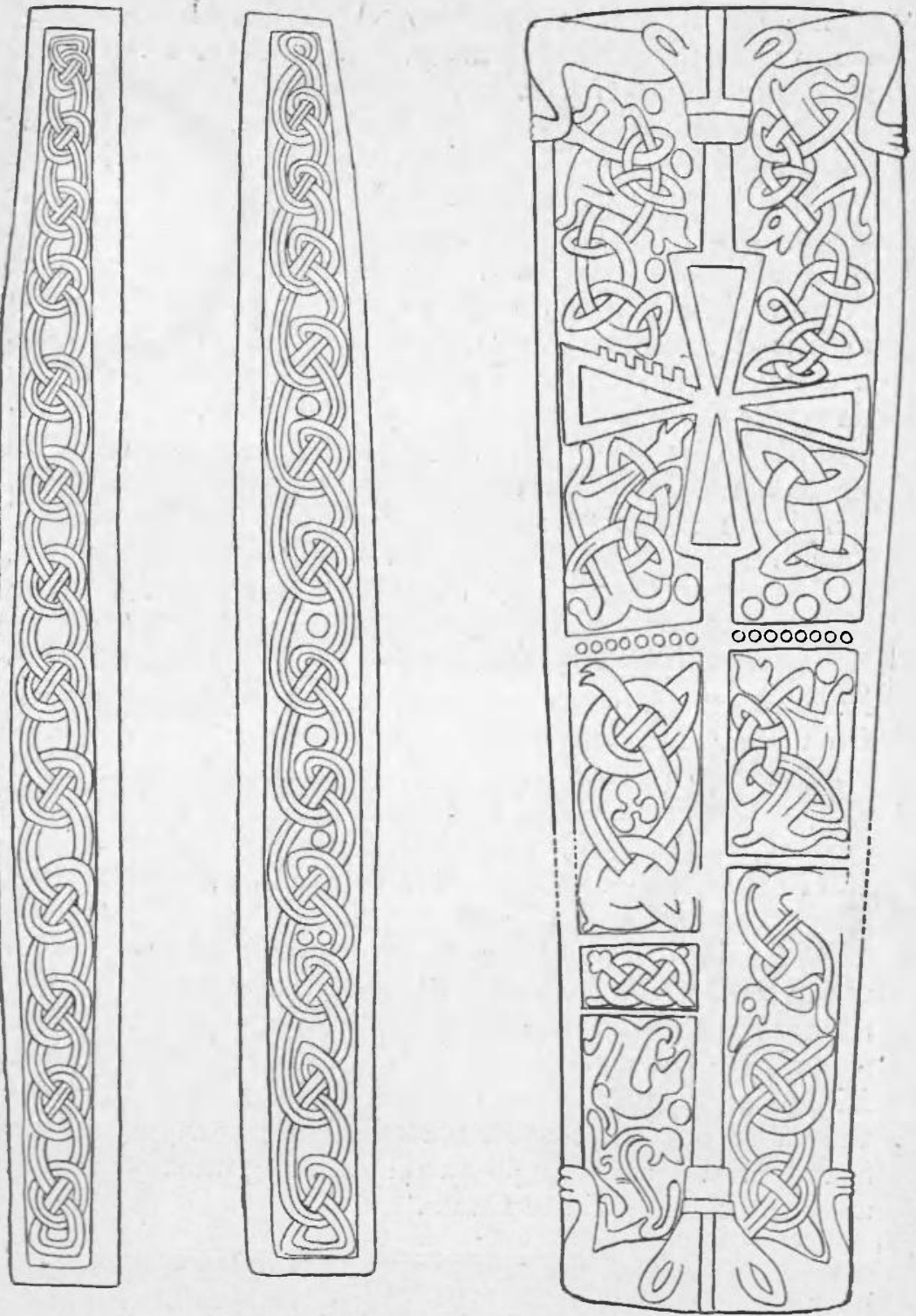

FIG. 5. GRAVE COVER, HICKLING, NOTTS. 
ments similar in character to the later cross-shafts in the neighbourhood.

In considering the question of dating these AngloSaxon remains of Nottinghamshire, we must remember that conquest has repeatedly divided English history by sharp lines, with new education, new arts, new architecture springing up afterwards.

In the ninth century the Danish invasion had made such a division, and Nottinghamshire was specially affected by it. English christianity and English art suffered eclipse during that period, and it was only between the accession of Canute in 1017 and the Norman Conquest that Northumbria was restored to christianity, and English artistic development there took new life. But there was a certain amount of revival begun under Alfred and his daughter Ethelflaed, the 'Lady of the Mercians,' and continued under Dunstan, which must have been felt as far north as the Humber. During this tenth century, Nottingham was 'occupied by English as by Danes,' Saxons and Vikings recognised a common Christian faith, and sepulchral monuments of both peoples might well be found side by side in this neighbourhood.

All the later examples of sepulchral crosses seem to have spread into Nottinghamshire from Lincolnshire or from the south, rather than from the northern Yorkshire border. To one or other of these two periods, the first half of the tenth century or the first half of the eleventh century, the Hawksworth group of crosses seems to belong. I am inclined to attribute them to the former period, the times of Alfred and Dunstan.

Traditions of Anglian sculpture had somehow survived, and the older Celtic ornamentation so completely adopted by Northumbria, though now grown stiff and formal, still preserved some of its characteristic features. Meanwhile another stream of art, derived no doubt from the same original source, was mingling with it, as the Scandinavian and Anglo-Saxon races gradually united after the coming of the Danes. 